\title{
GROWTH AND YIELD PREDICTION USING THE MODIFIED BUCKMAN MODEL ${ }^{1}$
}

\author{
Antonilmar Lopes da Silva², João Carlos Chagas Campos ${ }^{3}$, Helio Garcia Leite ${ }^{3}$, Agostinho Lopes de \\ Souza $^{3}$ e Pablo Falco Lopes ${ }^{4}$
}

\begin{abstract}
A model to manage even-aged stands was developed using a modification of the Buckman model. Data from Eucalyptus urophylla and Eucalyptus cloeziana stands located in the Northern region of Minas Gerais State, Brazil were used in the formulation of the system. The proposed model generated precise and unbiased estimates in non-thinned stands.
\end{abstract}

Keywords: Buckman model, growth and yield, basal area growth.

\section{PREDIÇÃO DE CRESCIMENTO E PRODUÇÃO USANDO O MODELO BUCKMAN MODIFICADO}

\begin{abstract}
RESUMO - Desenvolveu-se um modelo para o manejo de florestas equiâneas usando-se uma modificação do modelo de Buckman. Foram utilizados na formulação do sistema dados provenientes de povoamentos de Eucalyptus urophylla e Eucalyptus cloeziana localizados na região Norte do Estado de Minas Gerais, Brasil. O modelo proposto gerou estimativas precisas e não tendenciosas para povoamentos não desbastados.
\end{abstract}

Palavras chaves: modelo Buckman, crescimento e produção, crescimento de área basal.

\section{INTRODUCTION}

One of the three essential elements of forest management is prognosis, that is, growth and yield prediction. Forests cannot be managed without proper information on the future availability of wood and/ or sub-products. Such information is obtained by growth and yield models.

Buckman (1962) and Clutter (1963) were the first researchers to explain the mathematical relationships between growth and yield. Clutter derived compatible models for growth and yield in cubic volume of Pinus taeda, ensuring that the algebraic form of the yield model could be derived by the mathematical integration of the growth model. Later, Sullivan and Clutter (1972) perfected this model, resulting simultaneously in yield and accumulated growth estimates, as a function of an initial age, projected age, site index and basal area.

A model to estimate the yield, using age, site index, Reineke index and a competition index as independent variables was fitted to natural Pinus taeda plantations by MacKinney and Chaiken (1939). According to Avery and Burkhart (1994) many researchers have since used multiple regression techniques to predict growth and yield for total plantations or for some commercial portion of the plantation.

Buckman (1962) worked with periodic growth data from Pinus and used the following regression model to estimate the basal area growth rate in function of age, basal area and the site index: $d V=\beta_{0}+\beta_{1} B+\beta_{2} B^{2}+$ $\beta_{3} I+\beta_{4} I^{2}+\beta_{5} S$, where $d V=$ net annual periodic increment

\footnotetext{
${ }^{1}$ Recebido em 13.07.2005 e aceito para publicação em 05.04.2006.

${ }^{2}$ Veracel Celulose e Papel, Eunápolis, Bahia State, Brazil.

${ }_{3}^{3}$ Departamento de Engenharia Florestal da Universidade Federal de Viçosa, Viçosa, Minas Gerais State, Brazil. E-mail: $<$ hgleite@ ufv.br>.

${ }^{4}$ Forest engineering graduate student, UniversidadeFederal de Viçosa. Viçosa, Minas Gerais State, Brazil.E-mail: <pabloflopes@ hotmail.com>.
} 
of the basal area, $B=$ basal area, $I=$ age and, and $S=$ site index .

The author then substituted the basal area growth estimated by the equation derived from the previous model, and the height growth, in a differential form from a plantation volume equation, represented by $V=f(k, B, H d)$ where $V$ is the volume, $k$ a constant representing the mean form of the trees in the plantation, and $H d$ is the dominant height in the plantation. Summing the results, the author obtained estimates of net accumulated yield for several combinations of independent variables.

Later, Clutter (1963) formalized the relationships necessary between growth and yield observed in the Buckman model and developed equations to express net volume and growth rate of the basal area as function of age, from the site index and the plantation density, by differentiation of the yield function. Sullivan and Clutter (1972) refined this technique, estimating the cumulative yield and the growth as a function of the initial age of the plantation, the initial basal area of the site index and future age.

Several studies were carried out after 1972, including those by Beck and Della-Bianca (1972), Burkhart and Sprinz (1984), Trevizol Jr. (1985), Resende (1991) Campos et al. (1996) among many others, showing the flexibility of the Buckman model. In spite of this, the model has not been used in Brazil. In this country, the growth and yield modeling have always been conducted using the Clutter model (CAMPOS e LEITE, 2002).

This study was carried out with the objective of proving the efficiency of this model in predicting growth and yield in eucalyptus plantations in Brazil. For greater efficiency, a modification of the model is presented and fitted to Eucalyptus urophylla and Eucalyptus cloeziana plantations located in the northern region of Minas Gerais State, Brazil.

\section{MATERIALAND METHODS}

\subsection{Data used in the growth and yield study.}

The data used in this study were provided from Eucalyptus urophylla and Eucalyptus cloeziana plantation located in the northern region of Minas Gerais State. Two data sets were used from a research project implemented in 1988 by the Forest Research Society - SIF (Sociedade de Investigações Florestais) of the
Federal University of Viçosa, Minas Gerais, Brazil. Each set consists of two groups of 30 permanent $500 \mathrm{~m}^{2}$ plots measured at ages ranging from 28 to 96 months. When the project was established, the variations in site quality were considered and the initial spacing was $3.0 \times 1.5 \mathrm{~m}$. On each occasion the following parameters were measured: the diameter at $1.30 \mathrm{~m}(d b h)$ of all the trees, the total height of the trees of the first row of each plot and the total height of ten dominant trees.

Data from 225 sample trees (130 Eucalyptus urophylla and 95 Eucalyptus cloeziana trees) were used to fit the volumetric model. These trees were felled and cubed using the Smalian formula, with 1.0 $\mathrm{m}$ long sections and included diameters between 4 and $18 \mathrm{~cm}$ and total heights between 5 and $24 \mathrm{~m}$.

\subsection{Site quality, height and volume per tree}

The site quality was determined using the guidecurve method (CAMPOS e LEITE, 2006) and ChapmanRichards model, employing the following expression:

$$
S=H d\left(1-e^{-\beta_{1} A_{i}}\right)^{\beta_{2}}\left(1-e^{-\beta_{1} A}\right)^{-\beta_{2}}
$$

where $H d=$ heights of dominant trees, m, $A=$ age in months and $\beta_{0}, \beta_{l}, \beta_{2}=$ parameters, $A_{i}=$ index age $=66$ months.

The following models were fitted to estimate the total heights per tree:

$H t=\beta_{0}+\beta_{1} A+\beta_{2} S+\beta_{3} \operatorname{Lndbh}+\beta_{4} \operatorname{Lndbh} . A+\beta_{5} \operatorname{Ln} A+\varepsilon$, where $H t=$ total height, $S=$ site index, and $\beta_{r}, d b h$, $A$ and $\varepsilon$ as previously defined.

The volumetric model proposed by Leite et al. (1995) was fitted to quantify the volume per tree. The coefficient of determination and the graphic analyses of the residues were the statistics used to assess the estimates generated by all the equations fitted in this study.

\subsection{Growth and Yield model}

After obtaining the totalized plots, the model

$$
L n d B=\beta_{0}+\beta_{1} A+\beta_{2} S+\beta_{3} A^{-1}+\beta_{4} \operatorname{LnB} 1
$$

was fitted, where $d B=$ net periodic increase of the basal area, $\mathrm{m}^{2} \mathrm{ha}^{-1}, \mathrm{~B}_{1}=$ basal area at initial age, $\mathrm{m}^{2} \mathrm{ha}^{-1}$, $A, \mathrm{~S}, L n$ and $\beta_{\mathrm{i}}$ as previously defined.

The previous functional relationship is different from that proposed by Buckman (1962) and is a variation 
of the Schumacher model. Here the variable was included in the model based on results from some preliminary adjustments.

The yield in basal area $(B)$ was obtained by the sum of the successive increases, that is, for an interval of ages $A_{1}$ and $A_{2}$,

$$
B=\int_{A_{1}}^{A_{2}} e^{c+\beta_{1}+\beta_{3} A^{-1}} d A, \text { where } B=\text { basal area, }
$$

$\mathrm{m}^{2} \mathrm{ha}^{-1}, A_{1}$ and $A_{2}=$ age 1 and age 2 , in months, $C=\beta_{0}+\beta_{2} S+\beta_{4} \operatorname{Ln} \beta_{1}$.

After obtaining the estimates of basal area increase and the height and yield capacity, the model suggested by Schumacher (1939) was used to predict the volume obtained $\operatorname{Ln} V=\beta_{0}+\beta_{1} S+\beta_{2} A^{-1}+\beta_{3} \operatorname{Ln} B+\varepsilon$, where $V=$ volume, in $\mathrm{m}^{3} \mathrm{ha}^{-1}, \beta_{0}, \beta_{1}, \beta_{2}, \beta_{3}=$ parameters to be estimated, and $A, B$ and $S$ as previously defined.

\section{RESULTS AND DISCUSSION}

The site quality was classified using the independent equations for the two species, using an age index $\left(A_{i}\right)$ equal to 66 months, and the following equations were obtained, respectively, for Eucalyptus cloeziana and Eucalyptus urophylla:

$H d=26.51124\left(1-e^{-0.013944 . A}\right)^{(1-0.112217)^{-1}}$, with $r_{Y Y}=0.905, Y=H d$,

$H d=20.62326\left(1-e^{-0.018998 . A}\right)^{(1-0.059762)^{-1}}$, with $r_{Y \hat{Y}}=0.759$.

The model fitted to estimate the total height, resulted in the following equations:

$$
\begin{aligned}
& H t=-24.0243-0.1773 A+0.5294 S+1.0789 L n d b h+ \\
& +0.0714 L n d b h . A+6.6414 \operatorname{LnA},
\end{aligned}
$$

with $R^{2}=0.944$ and $S_{Y X}=0.95 \mathrm{~m}$, for Eucalyptus cloeziana, and

$$
\begin{aligned}
& H t=-26.0664-0.1934 A+0.4913 S+1.3943 L n d b h+ \\
& +0.0641 L n d b h . A+7.7363 \operatorname{LnA}, \\
& \quad \text { with } R^{2}=0.910 \text { and } S_{Y X}=0.97 \mathrm{~m} \text {, for Eucalyptus } \\
& \text { urophylla. }
\end{aligned}
$$

These equations do not ensure meeting of the biological phenomenon involved, but they were efficient quantitatively for the height estimates and are useful when the mechanistic models do not apply.

The multiple volume equations obtained from the two species did not reveal bias in the estimates, proving their efficiency:

Eucalyptus cloeziana and $d b h \leq 10 \mathrm{~cm}$ :

$V=0.000116 d b h^{1.298786} H t^{1.213757} e^{-2.06221 . k /}$
$d b h\left(1-\left(\frac{d_{u}}{d b h}\right)^{1+0.51801 d u}\right), d b h \leq 10 \mathrm{~cm}, r_{V V}=0.980$, Eucalyptus cloeziana and $d b h>10 \mathrm{~cm}$ :

$V=0.000071 d b h^{1.59879} H t^{1.177664} e^{-3.90959 . k /}$

${ }^{\prime} d b h\left(1-\left(\frac{d_{u}}{d b h}\right)^{1+0.35880 d_{u}}\right), d b h>10 \mathrm{~cm}, r_{V \hat{V}}=0.976$

Eucalyptus urophylla and $d b h \leq 12 \mathrm{~cm}$ :

$V=0.000086 d b h^{1.329838} H t^{1.322434} e^{-2.29267 . k /}$

$d b h\left(1-\left(\frac{d_{u}}{d b h}\right)^{1+0.448761 d_{u}}\right), d b h \leq 12 \mathrm{~cm}, R_{V \hat{V}}=0.971$

Eucalyptus urophylla and $\mathrm{dbh}>12 \mathrm{~cm}$ :

$V=0.000054 d b h^{1.837853} H t^{1.044908} e^{-3.18198 . k /}$

$d b h\left(1-\left(\frac{d_{u}}{d b h}\right)^{1+0.30719 d_{u}}\right), d b h>12 \mathrm{~cm}, R_{V \hat{V}}=0.984$

where $V=$ volume in $\mathrm{m}^{3}, d b h=$ diameter outside bark in $\mathrm{cm}$ measured at $1.30 \mathrm{~m}, k=$ dummy variable, where $k=0$ volume outside bark and $k=1$ volume inside bark, and $d_{u}=$ commercial superior diameter, outside bark, in $\mathrm{cm}$.

The growth and yield estimates were obtained from the annual measurements of the permanent plots. However, in this study, the annual growth was transformed in mean monthly growth, which corresponds

R. Árvore, Viçosa-MG, v.30, n.5, p.787-793, 2006 
to the mean point of the measurement interval of one year. For this purpose the following equations were generated:

$L n d B=0.1046-0.0279 A+0.0668 S-66.9749 A^{-1}+0.0651 \operatorname{Ln} B_{1}(1)$, with $R^{2}=0.450$, for Eucalyptus urophylla, and $\operatorname{Lnd} B=2.516-0.04328 A+0.083 S-105.6486 A^{-1}-0.518 \operatorname{Ln} B_{1}(2)$, with $R^{2}=0.710$, for Eucalyptus cloeziana.

This model fitted best the basal area increase data. All the independent variables were significant at $1 \%$ probability. The inclusion of the age variable twice in the model eliminated an undesirable tendency ascertained when using the model in its original form, and despite a "low" $R^{2}$, the distribution of the percentage residues can be considered acceptable (Figure 1).

The basal area yield can be obtained from the sum of the basal area increases by differential equations, or by approximations of a table of basal area growth, or by repeated solution of the basal area growth function. It can be written that $d B=\frac{d B}{d A}=e^{c-0.0279 A-66.9749 A^{-1}}$ and $d B=\frac{d B}{d A}=e^{c-0.04328 A-105.64286 A^{-1}}$ (4) for, respectively, Eucalyptus urophylla and Eucalyptus cloeziana, where $d B$ is the basal area growth, $B$ the yield in basal area, $d B / d A$ the change in the basal area with age, and $C$ a constant that contains the terms $S$ (site index), $\operatorname{Ln} B_{1}$ (logarithm of the initial basal area) and the $\beta_{0}$ value (intercept). Integration of the growth equations generates the yield function.

If a function $f(x)$ is continuous in an interval [a,b]

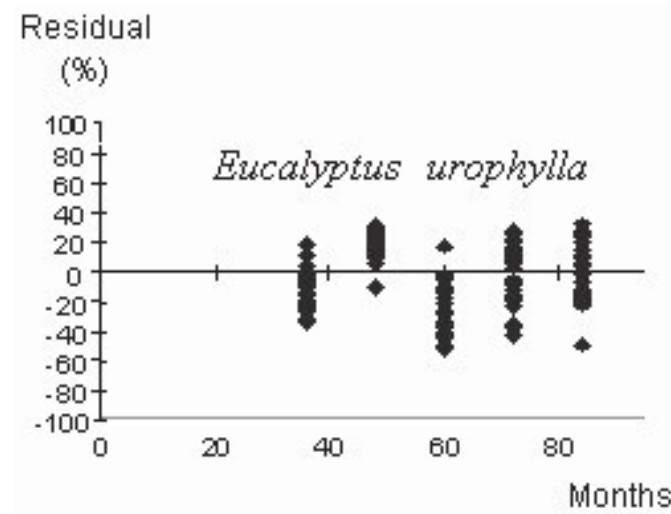

its primitive $\mathrm{F}(\mathrm{x})$ can be known, corresponding to the integral defined of this function, in this interval. Thus:

$$
\int_{a}^{b} f(x) d x=F(b)-F(a)
$$

In the case of this study, the primitive value of $\mathrm{F}(\mathrm{x})$ is not known or easily obtained. Thus, to calculate the value of the defined $f(x)$ integral, a numerical method had to be used. The Newton-Cortes formulas were used that employed $f(x)$ values, where the $x$ values were equally spaced (monthly values). Specifically among the Newton-Cortes formulas the compound formula of the $1^{\text {st }}$ Simpson rule was used (BARROSO et al., 1982). This rule is obtained by approximating the function $f(x)$ by a $2^{\text {nd }}$ degree interpoled polynomial.

Thus $f(x)=P_{2}(x)=y_{0}+z \Delta y_{0}+\frac{z(z-1)}{2 !} \Delta^{2} y_{0}$ and

$A=\int_{a}^{b} f(x) d x=\int_{a}^{b} P_{2}(x) d x=\int_{a}^{b}\left[y_{0}+z \Delta y^{0}+\frac{z(z-1)}{2 !} \Delta^{2} y_{0}\right] d x$

Developing this integral, we obtain $A=\frac{h}{3}\left(y_{0}+4 y_{1}+y_{2}\right)$ (6), which is the $1^{\text {st }}$ Simpson rule. To obtain the compound formula, the integration interval $[a, b]$ should be divided into $n$ equal subintervals of $h$ amplitude and the $1^{\text {st }}$ Simpson rule should be applied to each pair of subintervals. Thus, it follows that

$$
\begin{aligned}
& n=\frac{b-a}{h}, x_{i} ; i=0,1,2, \ldots, n, \quad I=\int_{a}^{b} f(x) d x \\
& A=\frac{h}{3}\left[y_{0}+4 y_{1}+y_{2}\right]+\frac{h}{3}\left[y_{2}+4 y_{3}+y_{4}\right]+\ldots .+\frac{h}{3}\left[y_{n-2}+4 y_{n-1}+y_{n}\right] \\
& A=\frac{h}{3}\left[y_{0}+4 y_{1}+2 y_{2}+4 y_{3}+2 y_{4}+\ldots .+2 y_{n-2}+4 y_{n-1}+y_{n}\right]
\end{aligned}
$$

\section{Residual}

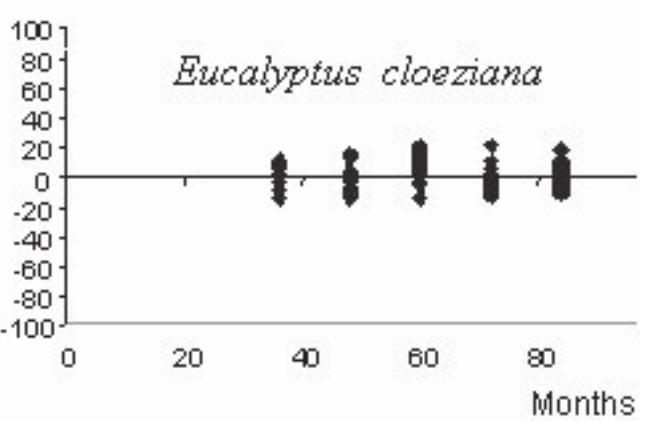

Figure 1 - Distribution of percent residues of the basal area increase estimates.

Figura 1 - Distribuição dos resíduos porcentuais das estimativas de incremento em área basal.

R. Árvore, Viçosa-MG, v.30, n.5, p.787-793, 2006 
Applying the Simpson rule to the growth function in Eucalyptus urophylla basal area,

$B=\int_{a}^{b} e^{(C-0,0279 A-66,9749 / A)} d A$ was obtained and $B$ is the yield in basal area $\left(\mathrm{m}^{2} \mathrm{ha}^{-1}\right)$ in the interval [a,b], and $C$ is the constant that contains $\beta_{0}+\beta_{2} S+\beta_{4} L n B_{1}$. For example, when considering the interval $\mathrm{a}=30$ months and $b=42$ months, a site index of 13 and an initial basal area (at 30 months) of 4.52331, we have

$B=\int_{30}^{42} e^{\left(1.07125-0,0279 A-66.9749 A^{-1}\right)} d I$

The first subinterval $y_{0}$ for age 30 months is

$y_{0}=e^{(1.07125-0.0279(30)-66.9749 / 30)}=0.13557$

The second subinterval $y_{1}$ for 31 months is $y_{1}=e^{(1.07125-0.0279(31)-66.9749 / 31)}=0.14169$

The last subinterval $y_{n}$ for age 42 months is $y_{1}=e^{(1.07125-0.0279(42)-66.9749 / 42)}=0.18356$

Applying the subinterval values (12 months) in equation 7, we obtain $B=\int_{30}^{42} e^{(C-0.0279 I-66.9749 / A)} d A=1.96903\left(\alpha_{1}\right)$, which is a yield in basal area at the interval 30 to 42 months.

The possibility of integrating the growth functions allows proof of the compatibility between growth and yield. The sum of the basal area increases obtained at various subintervals of the interval $[a, b]$ is equal to the integral of the growth function at this same interval.

The second method of sum of the basal area increases results in the growth of the mean point of a determined interval (Figure 2).

The yield in basal area at the interval $[30,42]$ is obtained by multiplying the number of subintervals (12 months) by the growth obtained from the growth curve (equation 1) for example, for site index $S=13$ and initial basal area $B_{1}=4.5233$ at the mean point of the interval. The growth in basal area at 36 months is $d B=0.166$ and the yield in basal area in the period $[30,42]$ is $1.99 \mathrm{~m}^{2} \mathrm{ha}^{-1}\left(\alpha_{2}\right)$.

The third method to obtain yield in basal area consists of repeated solutions of the growth in basal area function. This method involves the solution of the growth equation for a determined site index, age and plantation density. The growth is then added to the initial density of the plantation, one month is added to the age and the equation is solved again. For example, for the same site index, 13 , considering equation 1 of basal area growth of 4.5233 and age ranging from 30 to 42 months, yield is obtained by repeated solutions. In this case, the yield in basal area in the 12 month period is $6.4640-4.5233-1.94$ $\mathrm{m}^{2} \mathrm{ha}^{-1}\left(\alpha_{3}\right)$.

The comparison of the results of the three methods, for the site index 13 and initial basal area of 4.5233 $\mathrm{m}^{2} \mathrm{ha}^{-1}\left(\alpha_{1}, \alpha_{2}\right.$ and $\left.\alpha_{3}\right)$ shows that the difference among them was small. Although not presented, the difference was even less for higher ages, within the interval studied. Therefore, any one of these methods can be used to estimate the basal area growth.

After obtaining the yield in basal area, the yield and growth in volume with bark can be estimated to build the yield table. The equations of plantation volume fitted with yield data as a function of the site index $(S)$ age $(I)$ and basal area $(B)$ for Eucalyptus urophylla and Eucalyptus cloeziana were, respectively

$$
\begin{aligned}
& \operatorname{Ln}\left(V_{c c}\right)=1.1463+0.0479 . S-25.0645 / A+1.1678 . \operatorname{Ln}(B) \\
& \operatorname{Ln}\left(V_{c c}\right)=1.1300+0.0664 . S-31.2344 / A+1.1215 \cdot \operatorname{Ln}(B)
\end{aligned}
$$

With determination coefficients 0.998 and 0.998 .

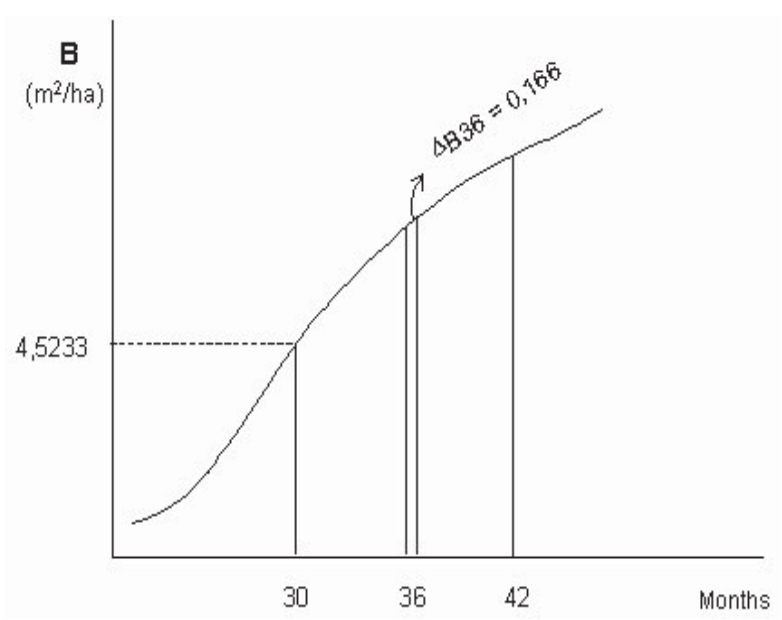

Figure 2 - Growth in basal area at the mean point of the 30 to 42 month interval $\left(\mathrm{dB}_{36}\right)$ for Eucalyptus urophylla, site index 13 and initial basal area of $4.5233 \mathrm{~m}^{2} \mathrm{ha}^{-1}$

Figura 2 - Crescimento em área basal no ponto médio do intervalo de 30 a 42 meses $\left(d B_{36}\right)$ para Eucalyptus urophylla, índice de local 13 érea basal inicial de 4,5233 $\mathrm{m}^{2} \mathrm{ha}^{-1}$.

R. Árvore, Viçosa-MG, v.30, n.5, p.787-793, 2006 
The increase in volume is obtained by deriving equation 8 , for age, that is

$$
\begin{aligned}
& d V / d A=V\left[-b_{2} / A^{2}+b_{3} / B^{*} d B / d A\right] \\
& d V / d A=V\left[25.0645 / A^{2}+1.1678 / B^{*} d B / d A\right]
\end{aligned}
$$

The yield tables or curves are obtained by the calculation of the increase and yield in basal area and the growth and yield in volume, as shown in Table 1 , for some ages. In this table, the increase in basal area obtained from equation 1 is shown in column 2 . The method of obtaining yield in basal area by repeated solutions results in the total basal area (column 3 ). Replacing the total basal area in equation 8 , yield in volume is obtained (column 4 ). The felling age, from the point of view of mean yield, occurs when the mean monthly increase (column 6) is maximum and equal to the monthly periodic increase (column 5) in the example, 96 months. Finally increase in volume can be obtained, using equation 11 (column 7) and summing the increases in volume, the yield in volume is obtained (column 8 ). No type of tendentiousness was observed in the growth and yield estimates and they can be considered precise (Figure 3 ).

Table 1 - Table of variable density yield for Eucalyptus urophylla in the Northern Region of Minas Gerais State, Brazil, with initial basal area of $4.5233 \mathrm{~m}^{2} \mathrm{ha}^{-1}$ and site index 13

Tabela 1 - Tabela de produção de densidade variável de Eucalyptus urophylla, na região de Montes Claros, Minas Gerais, com área basal inicial de 4,523 $\mathrm{m}^{2} \mathrm{ha}^{-1}$ e índice de local 13

\begin{tabular}{cccccccc}
\hline Age & $\begin{array}{c}\text { Increase Área } \\
\text { Basal } \\
\left(\mathrm{m}^{2} \mathrm{ha}^{-1}\right)\end{array}$ & $\begin{array}{c}\text { Basal } \\
\text { area } \\
\left(\mathrm{m}^{2} \mathrm{ha}^{-1}\right)\end{array}$ & $\begin{array}{c}\text { Volume } \\
\left(\mathrm{m}^{3} \mathrm{ha}^{-1}\right)\end{array}$ & $\begin{array}{c}\text { Monthly periodic } \\
\text { increase } \\
\left(\mathrm{m}^{3} \mathrm{ha}^{-1}\right)\end{array}$ & $\begin{array}{c}\text { Monthly mean } \\
\text { increase } \\
\left(\mathrm{m}^{3} \mathrm{ha}^{-1}\right)\end{array}$ & $\begin{array}{c}\frac{d V}{d A} \\
\left(\mathrm{~m}^{3} \mathrm{ha}^{-1}\right)\end{array}$ & $\begin{array}{c}\text { VOL+ } \frac{d V}{d A} \\
\left(\mathrm{~m}^{3} \mathrm{ha}^{-1}\right)\end{array}$ \\
\hline 30 & 0,1356 & 4,6589 & 15,3405 & & 0,5114 & & \\
31 & 0,1417 & 4,8006 & 16,3207 & 0,9802 & 0,5265 & 0,9882 & 16,3287 \\
32 & 0,1474 & 4,9480 & 17,3401 & 1,0194 & 0,5419 & 1,0277 & 17,3484 \\
36 & 0,1664 & 5,5870 & 21,7996 & 1,1706 & 0,6055 & 1,1797 & 21,8087 \\
$\ldots$ & $\ldots$ & $\ldots$ & $\ldots$ & $\ldots$ & 1,0989 & 1,3229 & 92,3111 \\
84 & 0,1262 & 13,6759 & 92,3101 & 1,3219 & 1,1132 & 1,1199 & 106,8668 \\
96 & 0,0998 & 15,0155 & 106,8667 & 1,1199 & 1,1131 & 1,1030 & 107,9697 \\
97 & 0,0977 & 15,1133 & 107,9696 & 1,1030 & 1,1128 & 1,0861 & 109,0557 \\
98 & 0,0957 & 15,2090 & 109,0558 & 1,0861 & & &
\end{tabular}
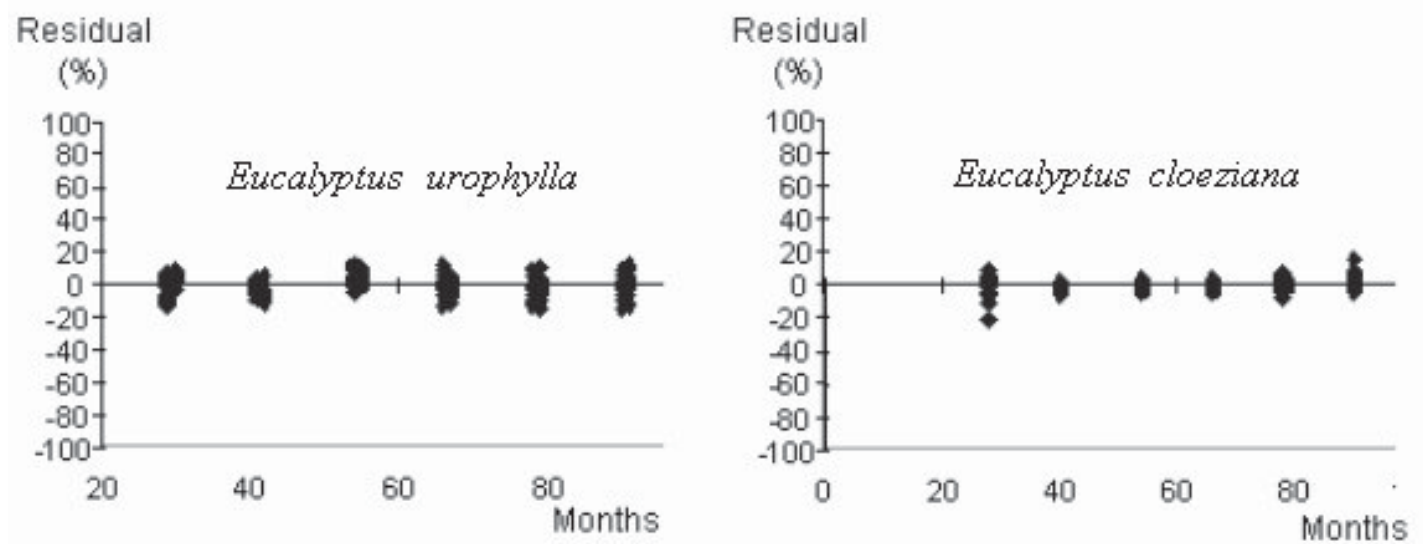

Figure 3 - Distribution of observed and estimated volume residues for Eucalyptus urophylla and Eucalyptus cloeziana projected by the growth and yield model.

Figura 3 - Distribuição de resíduos dos volumes observados e estimados pelo modelo de crescimento e produção de Eucalyptus urophylla e Eucalyptus cloeziana.

R. Árvore, Viçosa-MG, v.30, n.5, p.787-793, 2006 


\section{CONCLUSIONS}

The Buckman model, modified in this study, results in unbiased estimates and is indicated to estimate the present and future growth and yield of eucalypt plantations. Three alternatives for estimating the growth in basal area are presented, all of which are efficient.

\section{REFERENCES}

AVERY, T.E.; BURKHART, H.E. Forest measurements. 4.ed. New York: McGraw-Hill Book Co, 1994. 408 p.

BARROSO, L.C. et al. Cálculo numérico. 2.ed. Belo Horizonte: Harbra, 1982. 180 p.

BECK, D.E.; DELLA-BIANCA, L. Growth and yield of thinned yellow-poplar. Asheville: USFS, 1972. 20 p. (Res.Paper SE-101).

BUCKMAN, R.E. Growth and yield of red pine in Minnesota. Washington: U.S. Department Agriculture, 1962.50 p. (Technical Bulletin, 1272).

BURKHART, H.E.; SPRINZ, P.T. Compatible cubic volume and basal area projection equations for thinned old-field loblolly pine plantations.

Forest Science, v. 30, n. 1, p. 86-93, 1984.

CAMPOS, J.C.C.; LEITE, H.G. Mensuração

florestal: perguntas e respostas. Viçosa, MG: Editora UFV, 2006. 470 p

CAMPOS, J.C.C.; ROSAS, M.P.; LEITE, H.G. Comparação de alternativas de determinação da idade técnica de corte em plantações de eucalipto. Revista Árvore, v. 20, n. 1, p. 37-49, 1996.
CLUTTER, J.L. Compatible growth and yield models for loblolly pine. Forest Science, v. 9, n. 4, p. 354-371, 1963.

LEITE, H.G.; GUIMARÃES, D.P.; CAMPOS, J.C.C. Descrição e emprego de um modelo para estimar múltiplos volumes de árvores. Revista Árvore, v. 19, n. 1, p. 65-79, 1995.

MACKINNEY, A.L.; CHAIKEN, L.E. Volume, yield and growth of loblolly pine in the mid-atlantic coastal region. Washington: USDA Forest Service, 1939. 30p. (Technology Note,33).

RESENDE, R.R. Emprego de um modelo de crescimento e produção para determinação da rotação em povoamento de eucalipto. 1991. $81 \mathrm{f}$. Dissertação (Mestrado em Ciência Florestal) Universidade Federal de Viçosa, Viçosa, MG.

SCHUMACHER, F.X. A new grouth curve and its application to timber - yield. Journal Forestry, v. 37, p. 817-820, 1939.

SULLIVAN, A.D.; CLUTTER, J.L. A simultaneaous growth and yield model for loblolly pine. Forest Science, v. 18, p. 76-86, 1972.

TREVIZOL Jr, T.L. Análise de um modelo compatível de crescimento e produção em plantações de Eucalyptus grandis (W. Hill ex Maiden). 1985. 74 f. Dissertação (Mestrado em Ciência Florestal) - Universidade Federal de Viçosa, Viçosa, MG, 1985. 